INTERNATIONAL MONETARY FUND

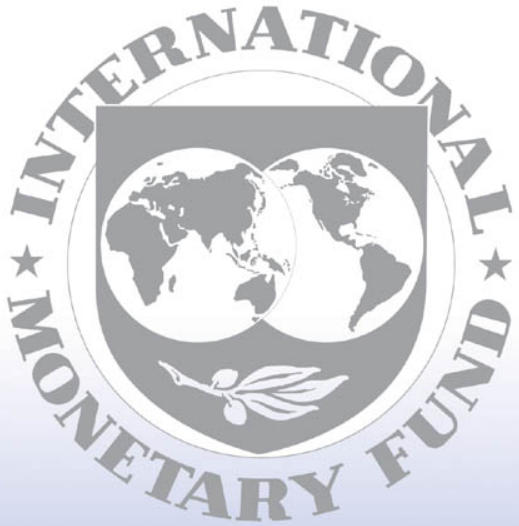

Staff

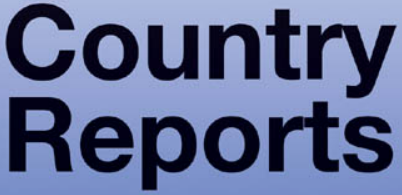




\section{Iceland: Stand-By Arrangement-Interim Review Under the Emergency Financing Mechanism}

In the context of the Stand-By Arrangement for Iceland under the Emergency Financing Mechanism, this paper on the Stand-By Arrangement-Interim Review Under the Emergency Financing Mechanism for Iceland was prepared by a staff team of the International Monetary Fund. It is based on the information available at the time it was completed on December 24, 2008. The views expressed in this document are those of the staff team and do not necessarily reflect the views of the government of Iceland or the Executive Board of the IMF.

The policy of publication of staff reports and other documents allows for the deletion of marketsensitive information.

Copies of this report are available to the public from

International Monetary Fund • Publication Services

$70019^{\text {th }}$ Street, N.W. $\bullet$ Washington, D.C. 20431

Telephone: (202) 623-7430 • Telefax: (202) 623-7201

E-mail: publications@imf.org •Internet: http://www.imf.org

\section{International Monetary Fund \\ Washington, D.C.}


This page intentionally left blank

CInternational Monetary Fund. Not for Redistribution 
INTERNATIONAL MONETARY FUND

\section{ICELAND}

\section{Stand-By Arrangement—Review Under the Emergency Financing Mechanism}

Prepared by the European Department in Consultation with Other Departments

Approved by Ajai Chopra and Tessa van der Willigen

December 24, 2008

- Summary. The crisis is producing the expected sharp economic contraction, but despite the liberalization of all current account transactions, pressures towards currency depreciation appear to have abated somewhat. The discussions focused on the next steps toward normalizing the monetary and exchange rate regime, and progress with fiscal policy commitments, bank restructuring, and external financing. The stabilization of the foreign exchange market appears to have boosted confidence in policies, and the central bank is confident that the stage is being set for a gradual reduction in policy rates and liberalization of capital controls starting in 2009. Regarding fiscal policy, the budget for 2009 is in line with program commitments, and preparations of the medium-term consolidation plan are on track. The authorities indicated that they may already legislate measures during 2009. As to financial sector restructuring, important progress is being made, although the authorities indicated that the valuation of bank assets and, therefore, the recapitalization of banks may be delayed by $4-8$ weeks, reflecting complicated discussions with creditors and auditors over methodology. New concerns have arisen in the savings bank sector (representing about 30 percent of deposit liabilities), which the authorities are working to address. They indicated that negotiations with bilateral creditors over committed loans would resume in January.

- Discussions: During December 15-19, 2008 the staff team met with the Prime Minister, Mr. Haarde; the Chairman of the Central Bank of Iceland, Mr. Oddsson; the Minister of Finance, Mr. Mathiesen; the Permanent Secretary of the Prime Minister's Office, Mr. Bollason; and other senior officials; as well as the CEOs of the new banks, and the leaders of the employers federation and of labor unions. An extensive outreach effort was conducted to introduce the program to the various segments of Iceland's society and discuss its implementation and challenges ahead. This effort involved meetings with major media outlets, parliamentarians, academics, and public sector representatives.

- Staff: The staff team comprised Mr. Thomsen (head); Messrs. Flanagan and Luzio, and Ms. Chivakul (all EUR); Ms. Gaviria-Baptiste (EXR); Mr. Gray (MCM); and Ms. Stuart (SPR). Mr. Olafsson (OED) attended many meetings. 


\section{INTRODUCTION}

1. On November 19, 2008 the Executive Board approved a two-year Stand-By Arrangement (SBA) for Iceland under the Emergency Financing Mechanism (EFM), in the amount of SDR 1.4 billion ( $\$ 2.1$ billion, 1190 percent of Iceland's quota). A first purchase of SDR 560 million was made following the Board meeting. The EFM calls for a review of the initial policy response and the reaction of markets to the authorities' policies within one to two months of the approval of the arrangement.

\section{RECENT DEVELOPMENTS AND OUTLOOK}

\section{The crisis is producing a sharp contraction of economic activity, as expected} (Figure 1; Table 1). Indicators of consumption are plummeting, and the deterioration in the labor market is accelerating, with rising unemployment and falling real wages contributing to a considerable contraction in real incomes. Significant import compression is underway allowing a sustained turnaround in the trade balance, as exports continue to benefit from a weaker króna. Meanwhile, inflation has risen from 14 percent in September to 17.1 percent in November, in line with the program.

3. The exchange rate has stabilized. All current account transactions have been liberalized since November 28 and the interbank foreign exchange market was restarted on December 4 . The króna, which had depreciated by about 17 percent in the on-shore market since end-October, appreciated sharply after the interbank market restarted. It has settled around króna 160 to the euro, broadly in line with end-year program projections (Figure 2).

\section{Financial markets remain largely frozen, but interest in government paper} appears to be reviving (Figure 2). The króna interbank market is still inactive and equity markets remain under pressure with trade thin. Sovereign risk has remained elevated, with CDS spreads stabilizing around 1100 bps. In the primary debt market, two government bond auctions held in early December saw low investor appetite. However, a treasury bill auction held on December 19 saw extremely strong demand (at yields around 16 percent), helped by an increase in the margin between the deposit and repo rates of the central bank (CBI).

\section{New data suggest a slightly different base for program projections.}

- The base of the central bank's net credit to the private sector is lower than originally understood, reflecting reclassification of foreign exchange deposits and data corrections (Table 2). This does not affect the program's monetary targets, which were set in flow terms to account for the exceptional uncertainty at the time. The authorities have also published the preliminary balance sheets of the new banks, with 
small differences compared to data earlier provided to the staff (Table 3). A full monetary survey is not yet available (pending work on valuation of bank assets). ${ }^{1}$

- $\quad$ The fiscal cost of the October banking collapse is expected to be lower. To date $\$ 5.8$ billion in insured foreign deposits from the United Kingdom, Netherlands, and Germany have been identified in the overseas branches of Icelandic banks. This is lower than the initial estimate of $\$ 8.2$ billion, in part because ring-fencing of branches in other countries has made it possible to cover deposits through recovered assets.

- In the external sector, newly published third quarter data point to a higher-than-expected current account deficit (7.3 percent of GDP), but this was driven largely by unexpected developments on the income account related to the banking sector turmoil, and has few flow implications going forward (Table 4). Data for end-September suggest that the external debt of the banking sector reached around $\$ 95$ billion prior to the crisis (versus a previous estimate of $\$ 84.7$ billion). While a limited amount of external debt is held by the smaller Icelandic banks, most of it is with the old banks and so will need to be recovered or written down in the bankruptcy process. Thus, this does not affect the debt sustainability analysis.

\section{Policy Implementation}

\section{The program is meeting its near-term objective of stabilizing the króna, and} there is progress towards medium-term fiscal consolidation, but bank restructuring is somewhat behind schedule. Implementation of agreed monetary and fiscal policies has delivered results, and the authorities are broadly on track to comply with end-year quantitative PCs (text figure, Table 5). In this regard, they indicated that the exchange rate rebound had given a significant boost to confidence. There is progress in structural reforms, save for technical issues delaying the bank recapitalization timetable (Table 6). The authorities have been working determinedly to overcome administrative capacity constraints, with considerable technical assistance from the Fund in all key policy areas. ${ }^{2}$

\footnotetext{
${ }^{1}$ A safeguards assessment of the CBI has been initiated. Staff visited Reykjavik in December 2008, and held discussions with the CBI authorities and officials from the National Audit Bureau (NAB). The safeguards assessment should be completed no later than the first review under the Stand-By Arrangement.

${ }^{2}$ Intensive recent technical support from the Fund has covered: capital controls; the development of liquidity management instruments and foreign exchange market infrastructure; preparation of the 2009 budget and development of the medium-term fiscal consolidation plan; and bank restructuring.
} 
Iceland: Monetary Program Targets
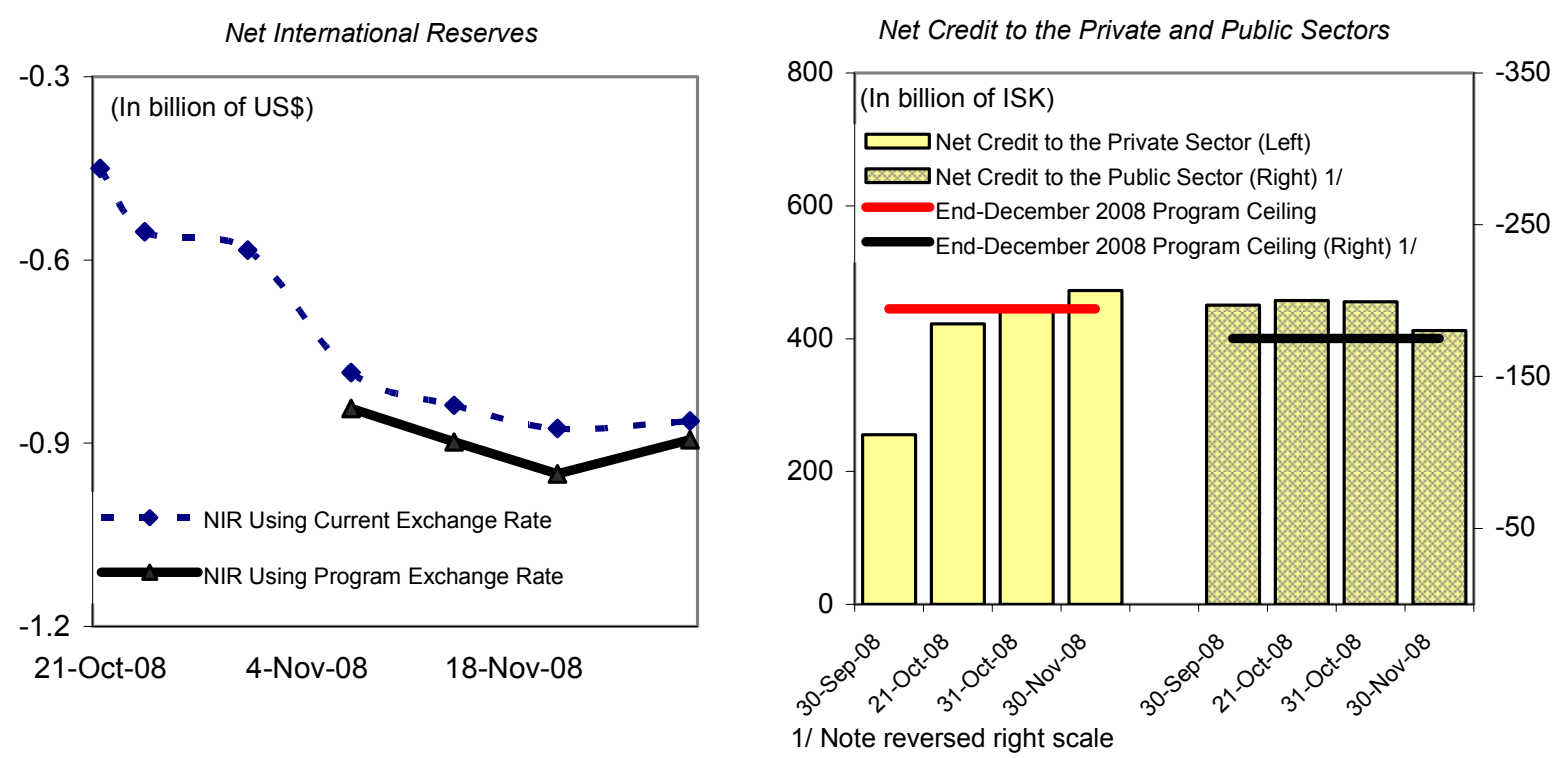

\section{A. Monetary and Exchange Rate Policy}

\section{After a turbulent initial period, which saw heavy foreign exchange intervention} and lending to banks, the monetary program is broadly on-track and delivering results:

- $\quad$ Overall foreign exchange market interventions have been moderate since October. The central bank's net foreign asset position remains well above the program floor. To help reduce króna volatility, the authorities are formulating an intervention strategy, which would have them react to excessive weekly movements in either direction, while anchoring overall interventions to NIR targets.

- The flow of central bank net credit to the private sector is above the program target for end-December, but it appears to be easing downwards towards the target. Improvements in the control of domestic currency liquidity will help. The authorities indicated that they intended to work further on their liquidity forecast, adjust the reserve requirement maintenance period, and control credit availability at the weekly open market operation (by fixing the volume).

- $\quad$ The CBI's policy interest rate has been kept at 18 percent, and the authorities and staff agreed that it was too early to contemplate a reduction. While the exchange rate has stabilized, significant downside risks remain, inflationary pressures have yet to abate, and a strategy for the elimination of capital controls has not yet been mapped out. The spread between the overnight rate and the deposit rate (i.e., the interest rate corridor around the policy rate) was widened on December 17. This was to encourage 
the interbank market, strengthen liquidity, and increase participation in government bond auctions.

\section{The capital controls introduced prior to the program have been formalized in}

legislation. The new formal controls exclude current items (for instance, interest payments), and limit capital flows between residents and nonresidents (but with a liberal treatment of FDI) (Table 7). On the whole, the market appears to have accepted that controls are unavoidable for now, but has called for less ambiguity in some areas. The CBI has been clarifying administrative arrangements and adapting FDI provisions to minimize circumvention. It plans to hold regular discussions with commercial banks to ensure transparency and evenhandedness in implementation. A full assessment of the effectiveness of the controls, and strategy for their gradual elimination will be a part of the first program review. The timeline would ultimately be driven by achievement of preconditions, such as the stability of the exchange rate, balance of payments prospects (not least the outlook for new capital inflows), and the level of international reserves.

\section{B. Fiscal Policy}

9. The draft 2009 budget is closely in line with the program (Table 8 ). The deficit would be $1 / 2$ percent of GDP higher compared to the program, reflecting refined estimates of automatic stabilizers (net of some interest savings). Measures to reverse the previously planned discretionary fiscal stimulus (i.e. to reduce it from 2.7 to 0.25 percent of GDP) would include increasing the PIT rate, and cutting operational costs by $3-5$ percent (Table 9). Regarding financing, the authorities and staff agreed that there were risks, related to very high gross financing needs and possible competition for pension fund resources (e.g., for corporate restructuring). The authorities indicated that they would review financing prospects in January, when they formulated their debt management strategy for 2009.

10. Medium-term fiscal consolidation plans are progressing, and the authorities are considering legislating measures already in 2009. They have started to cost the implications of some of the 2009 measures for the medium term, and they expect by late-December to have identified and discussed in cabinet the broad areas of focus for medium-term fiscal consolidation (a structural benchmark). To help identify measures, the authorities intend to draw on independent assessments of the efficiency of their tax and expenditure programs (e.g., from the OECD). They intend to legislate some of the mediumterm adjustment measures during 2009 to take advantage of a building consensus for upfront action.

\section{Net lending difficulties — a by-product of the banking collapse-may lead to} problems in meeting the end-2008 ceiling on the net financial balance. The overall fiscal balance through early-December is broadly on track, but net lending is above projections after the government could not unwind a securities lending transaction involving bad 
collateral and a weak counterparty. All else equal, the stock of outstanding government debt will thus be higher, implying a higher deficit (as measured under the program).

\section{Financial Sector Policy}

\section{Financial sector restructuring is moving forward in several areas:}

- A strategy for asset recovery has been put in place (meeting an end-November program benchmark). It involves an agreement with creditors to delay the sale of assets (and thus avoid "fire sale" prices). This has been supported by changes in the legal framework (extending the period under which there is a moratorium in place); the formal movement of all banks into a moratorium; and by the appointment of administrators to act in the interest of creditors. The mission noted that there was concern among some foreign creditors that the authorities' actions were nontransparent and might lead to unequal treatment. The authorities stressed that there had been no case of former shareholders acquiring assets of the intervened banks.

- The authorities have brought in a well-respected foreign expert to chair the bank restructuring committee. They considered it important to appoint someone with no close links to former shareholders to help reassure about the integrity of the process.

- $\quad$ Two of the three new banks have already submitted business plans for review. The authorities expect all three to have plans in place on schedule in mid-January.

- $\quad$ An expert has been hired to make an assessment of regulatory and supervisory practices, and should complete the assessment by end-March (as envisioned).

\section{A better picture of a feasible timetable for bank recapitalization is emerging, and determined action will be needed to stick to it:}

- $\quad$ The authorities believe that the work on valuation of bank assets can be complete by end-February or early-March. This reflects difficulty reaching agreement on a common methodology to be used: creditors needed to be consulted and auditors objections overcome (they objected to legal responsibility for an imposed methodology). The auditor hired by the authorities to manage the process, Oliver Wymann, is now adjusting the methodology. The process may be simplified by hiring one auditor to cover all three banks. The authorities acknowledged that to maintain the credibility of the process it would remain imperative to preserve an independent final view from the auditor managing the process.

- Due to delays in asset valuation, the timetable for bank recapitalization (a structural PC for end-February) will likely slip into late-March to early-April. Creditors of the old banks have also asked for more time to evaluate the structure of the bond that they will receive (in compensation for assets transferred to new banks), once the valuation 
process is complete. The authorities believe that to some extent this work can run parallel to the valuation effort, minimizing timing impacts.

\section{Evidence that the collapse of the three large banks has spilled over to small savings banks and other financial institutions suggests a need for prompt policy} reaction. The program had anticipated the possibility of adverse spillovers. It is now known that the collapse essentially wiped out the capital of savings banks and some institutions may be insolvent. New legislation permits the government to inject capital, up to 20 percent of the end-2007 book value (but contingent on write-downs by creditors). The three largest savings banks are in merger discussions, and smaller savings banks have been given a time limit to fix their capital position. Still, the total cost of this is likely to be small compared to the cost of dealing with the three large banks. It was agreed that it is a matter of urgency to handle this problem and in a manner that does not unsettle markets. This issue would be addressed in the context of the first program review.

15. The process of corporate and household debt restructuring has commenced. The government has given the boards of the new banks broad responsibilities to restructure loans on a case-by-case basis and they have begun to do so. The Housing Finance Fund is also restructuring loans. The authorities are considering a broader framework, including a fund to support restructuring (which would draw on resources from the pension fund and other investors). However, such a fund would require strong governance arrangements and would raise questions about fiscal financing prospects in 2009. It was agreed that the restructuring framework should be discussed further at the time of the first program review, once an independent advisor prepares a report on best international practice in this area.

\section{External Financing}

\section{The authorities are making good faith efforts to push negotiations with bank} creditors forward. There are regular monthly discussions with creditor committees, which will be further facilitated by appointment of independent financial advisors. Creditors have had input into the bank asset valuation methodology.

17. The program remains fully financed, but negotiations with bilateral creditors on the terms are not yet complete:

- $\quad$ Negotiations over deposit insurance loans, now expected to be $\$ 2.4$ billion less (see paragraph 5) will resume in early-January.

- The authorities indicated that they would soon begin negotiating the terms of the committed bilateral loans with the Nordic countries, and would be contacting the Russian and Polish authorities to begin similar negotiations. They, together with the Faroe Islands, have committed a total of $\$ 3.2$ billion. Most of the financing was programmed to be available in the fourth quarter of 2008, but is now expected to be delayed until early 2009 . 


\section{STAFF APPRAISAL}

18. The program is generally doing well. The key near-term objective of stabilizing the króna is being broadly met, although important near-term challenges remain, not least with regard to bank restructuring. Overall program objectives and measures remain appropriate, and steadfast implementation will be the key to success going forward.

\section{The monetary program is delivering results, but it is premature to alter the} policy stance. The combination of elevated interest rates, capital controls, and judicious intervention has allowed the exchange rate to broadly stabilize. Looking forward, upon continued evidence of stabilization and further strengthening of reserves, a sequenced capital account liberalization can be considered alongside a cautious reduction of interest rates.

20. The budget for $\mathbf{2 0 0 9}$ is broadly in line with the program, but financing needs to be secured, and the medium-term consolidation plan finalized. Fiscal flexibility remains the appropriate response to the crisis, but high gross financing needs signal a need to develop a comprehensive debt management strategy. Mapping out the medium-term consolidation remains a key near-term priority, and staff welcomes the authorities' assurances that political support for this challenging task is building.

21. Financial sector restructuring efforts are progressing, and the resolution process needs to be pushed forward at an ambitious, but feasible pace. A framework has been put in place for regular consultations with bank creditors, and good faith efforts are being made. Time has been taken to get the methodology for bank asset valuation correct and to consult with creditors. The process should not compromise on quality or credibility, but further delays would involve real economic costs. Attention must also be directed to savings banks and other financial institutions, where problems need to be rapidly resolved.

22. The program remains financed. It should be a matter of priority to reach early agreement on the terms of committed external financing, including financing earmarked for payments on guaranteed foreign deposits. Terms should be consistent with debt sustainability, taking into account uncertainty and risk considerations. 
Figure 1. Iceland: A Rapidly Cooling Economy
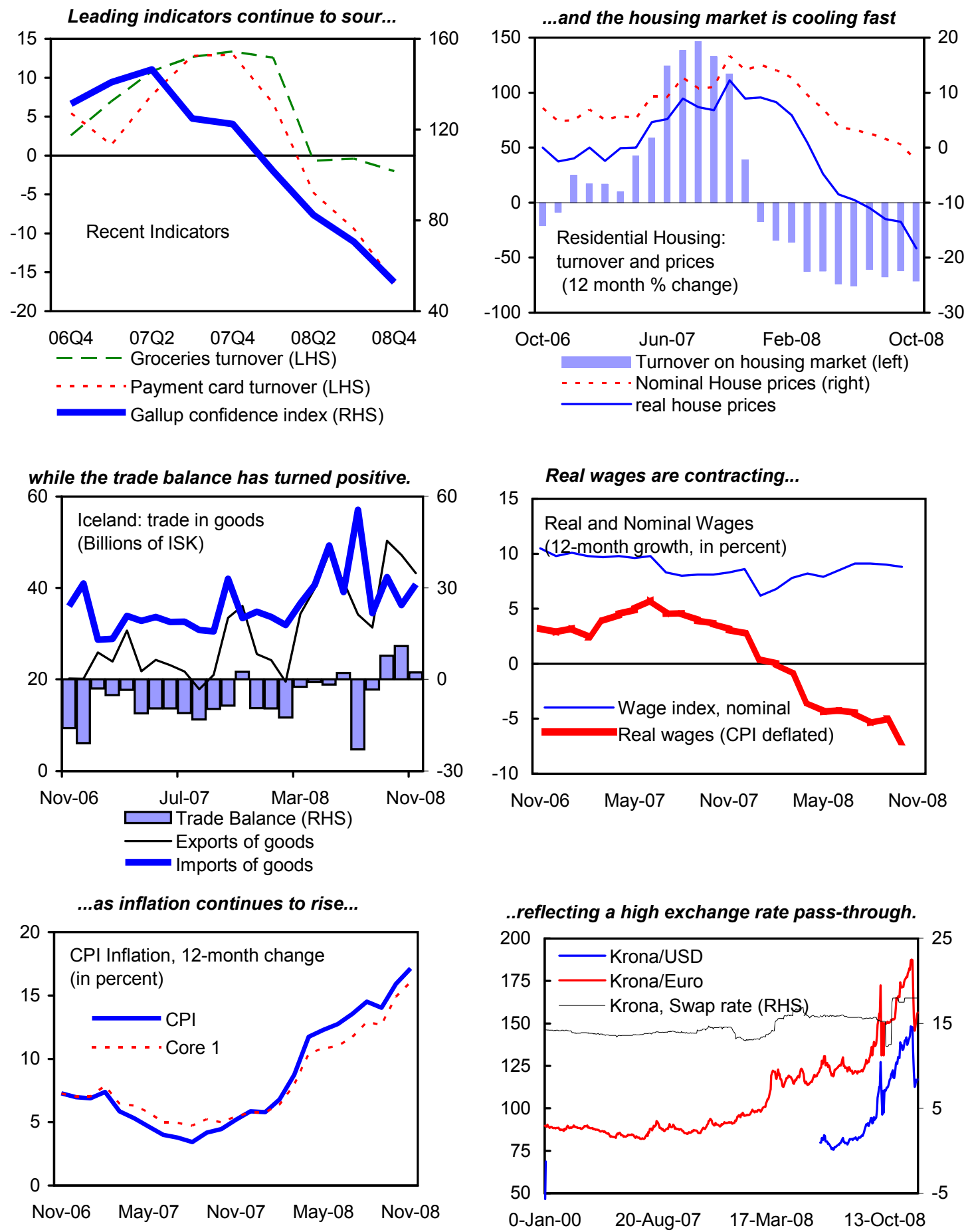

Source: Iceland Statistics; Bloomberg; IMF. 
Figure 2. Iceland: Recent Financial Market Developments
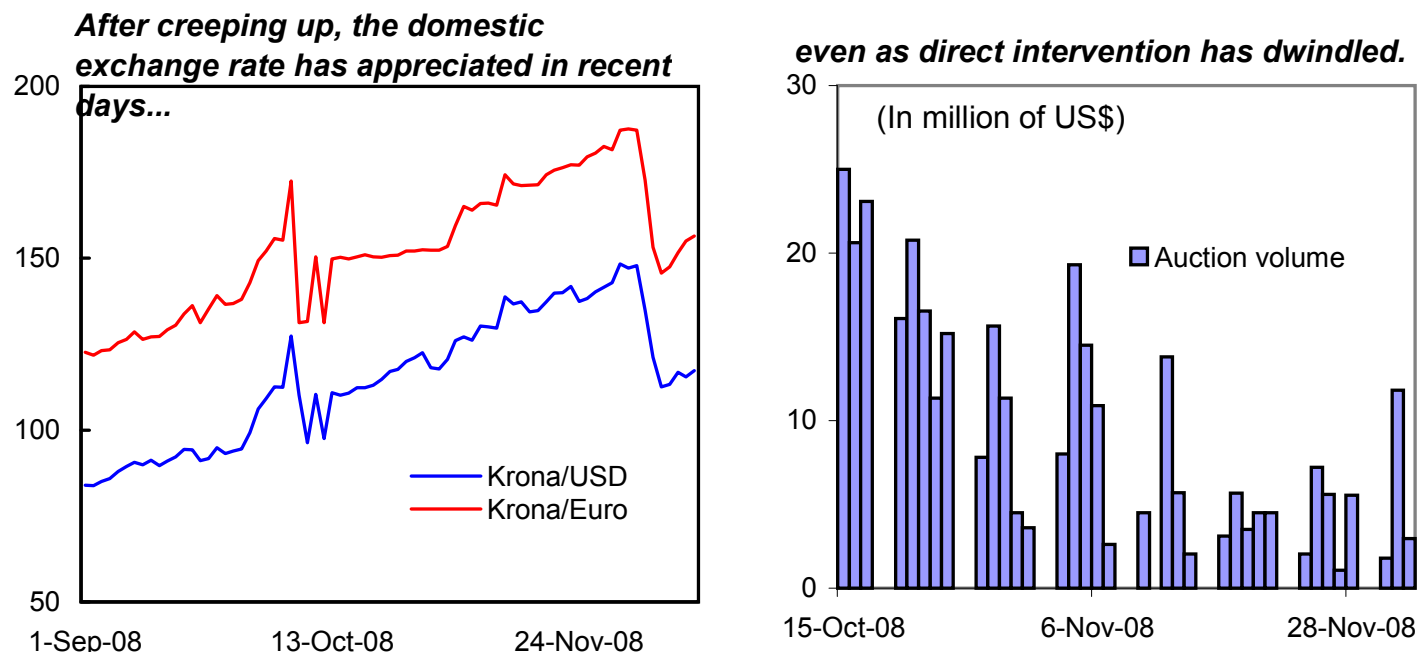

Equity prices have collapsed..
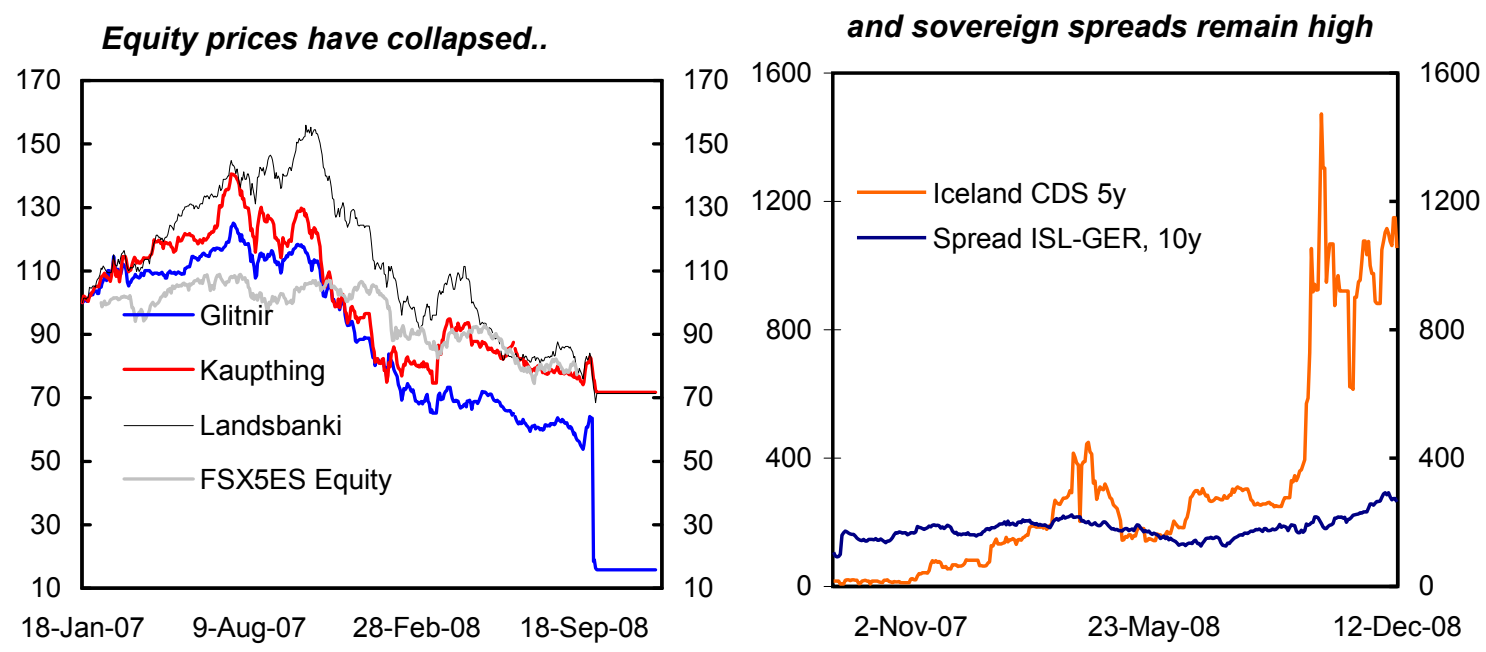

Source: Iceland Statistics; Bloomberg; IMF. 
Table 1. Iceland: Selected Economic Indicators, 2003-09

\begin{tabular}{lllllll}
\hline & 2003 & 2004 & 2005 & 2006 & 2007 & $\begin{array}{c}2008 \\
2009 \\
\text { est. }\end{array}$ \\
staff proj. staff proj.
\end{tabular}

(Percentage change unless otherwise noted)

National Accounts (constant prices)

Gross domestic product

Total domestic demand

Private consumption

Public consumption

Gross fixed investment

Export of goods and services

Imports of goods and services

Output gap 1/

\section{Selected Indicators}

Nominal GDP (bln ISK)

Central bank gross reserves (bln ISK)

Unemployment rate 2/

Real disposable income per capita

Consumer price index

Nominal wage index

Nominal effective exchange rate $3 /$

Real effective exchange rate (CPI) 3 /

Terms of trade

\section{Money and Credit}

Deposit money bank credit (end-period) of which to residents (end-period)

Broad money (end-period)

CBI policy rate (period average) 4/

$\begin{array}{rrr}2.4 & 7.7 & 7.4 \\ 5.6 & 10.0 & 16.0 \\ 6.1 & 7.0 & 12.9 \\ 1.8 & 2.2 & 3.5 \\ 11.1 & 28.1 & 35.7 \\ 1.6 & 8.4 & 7.2 \\ 10.7 & 14.5 & 29.4 \\ -4.7 & -1.2 & 2.3\end{array}$

4.4
9.9
4.4
4.0
20.4
-5.0
10.2
3.2

\section{9}

$-1.5$

4.3

4.2

$-13.7$

18.1

$-1.4$

4.8

$\begin{array}{rr}841.3 & 928.9 \\ 58.1 & 65.6 \\ 3.4 & 3.1 \\ -1.7 & 3.8 \\ 2.1 & 3.2 \\ 5.6 & 4.6 \\ 6.2 & 1.8 \\ 6.3 & 2.8 \\ -4.1 & -1.3\end{array}$

$1,026.4$
67.3

$1,167.9$

$1,293.2$

162.8

1.0

5.4

6.6

4.0

6.5

10.4

12.7

1.0

1.3

$-2.0$

6.8

9.1

5.0

9.3

$-10.7$

$-6.8$

3.5

2.7

5.7

0.1

$\begin{array}{rrrrr}26.7 & 41.9 & 76.0 & 44.4 & 56.6 \\ 20.0 & 37.2 & 54.7 & 33.6 & 28.3 \\ 17.5 & 15.0 & 23.2 & 19.6 & 56.4 \\ 5.3 & 8.2 & 10.5 & 14.1 & 13.8\end{array}$

Public Finance (in percent of GDP)

General government 5/

Balance of Payments (in percent of GDP)

Gross external debt

Central bank gross reserves (in months
Revenue

Expenditure

Balance

Structural balance

Current account balance

Trade balance (goods)

Financial and capital account $\mathrm{o} / \mathrm{w}$ : reserve assets $6 /$

Net errors and omissions of imports of goods and services) $7 /$

\begin{tabular}{rrrrrrr}
44.6 & 45.9 & 48.8 & 49.7 & 50.0 & 45.3 & 41.7 \\
47.5 & 45.9 & 44.0 & 43.4 & 44.5 & 45.5 & 55.2 \\
-2.8 & 0.0 & 4.9 & 6.3 & 5.5 & -0.2 & -13.5 \\
0.5 & 1.0 & 2.9 & 3.5 & 1.5 & -3.4 & -8.7 \\
& & & & & & \\
-4.8 & -9.8 & -16.1 & -25.4 & -14.6 & -29.5 & 2.3 \\
-1.9 & -3.9 & -9.1 & -13.4 & -6.8 & -2.6 & 5.5 \\
1.2 & 12.7 & 13.5 & 36.4 & 13.2 & -48.4 & -2.4 \\
-2.8 & -1.5 & -0.5 & -7.3 & -0.5 & 5.2 & 13.7 \\
3.6 & -2.9 & 2.6 & -11.0 & 1.4 & -12.2 & 0.0 \\
139.6 & 179.1 & 285.7 & 445.9 & 551.5 & 650.0 & 153.8 \\
& & & & & & \\
2.2 & 2.1 & 1.8 & 3.4 & 3.3 & 7.3 & 10.5 \\
\hline
\end{tabular}

Sources: Statistics Iceland; Central Bank of Iceland; Ministry of Finance; and staff estimates.

1/ Staff estimates. Actual minus potential output, in percent of potential output.

2/ In percent of labor force.

3/ A positive (negative) sign indicates an appreciation (depreciation).

4/ Data prior to 2007 refers to annual rate of return. 2007 and on, refers to nominal interest rate.

5/ National accounts basis.

6/ A positive (negative) sign indicates a decrease (increase) in gross official foreign reserves.

7/ Excluding imports from the construction of hydropower facility and smelters in 2003-04. 
Table 2. Iceland: Monetary Program Monitoring (In billion of ISK)

\begin{tabular}{|c|c|c|c|c|c|c|}
\hline & & & & & Project & tion $1 /$ \\
\hline & 30-Sep-08 & 21-Oct-08 & 31-Oct-08 & 30-Nov-08 & 31-Dec-08 & 31-Dec-09 \\
\hline Net international reserves & 93.9 & -51.3 & -73.1 & -118.4 & -87.5 & -309.7 \\
\hline NIR (in US\$ million) & 0.87 & -0.45 & -0.61 & -0.84 & -0.77 & -2.72 \\
\hline Net domestic assets & 149.3 & 350.5 & 377.1 & 415.6 & 397.8 & 595.8 \\
\hline Net claims on the public sector & -197.0 & -200.2 & -199.3 & -180.5 & -175.2 & -75.2 \\
\hline Net credit to the private sector $3 /$ & 485.6 & 690.0 & 718.8 & 743.5 & 722.2 & 798.2 \\
\hline Credit to banks 4 / & 455.0 & 605.2 & 733.6 & 759.6 & 627.5 & 725.4 \\
\hline Other, net 4/ & 30.6 & 84.7 & -14.8 & -16.1 & 84.7 & 84.7 \\
\hline Capital and reserves & -139.3 & -139.2 & -142.4 & -147.4 & -149.1 & -127.2 \\
\hline Base Money & 243.2 & 299.3 & 304.0 & 297.2 & 310.3 & 286.0 \\
\hline Currency issued & 12.6 & 32.1 & 28.9 & 26.4 & 33.2 & 30.8 \\
\hline Reserve deposits $3 /$ & 230.6 & 267.2 & 275.1 & 270.8 & 277.1 & 255.2 \\
\hline Memo item: & & & & & & \\
\hline Net credit to the private sector (TMU definition) $5 /$ & 255.0 & 422.8 & 443.7 & 472.7 & 445.0 & 543.0 \\
\hline Total assets & 877.0 & $1,132.4$ & $1,197.1$ & $1,322.7$ & $\ldots$ & $\ldots$ \\
\hline Foreign assets & 374.8 & 382.4 & 408.1 & 506.6 & $\ldots$ & $\ldots$ \\
\hline Bank balances (inc. gold and IMF SDR) & 125.3 & 142.1 & 169.3 & 277.5 & $\ldots$ & $\ldots$ \\
\hline Debt securities & 249.5 & 240.3 & 238.9 & 229.0 & $\ldots$ & $\ldots$ \\
\hline Domestic assets & 502.2 & 749.9 & 789.0 & 816.1 & $\ldots$ & $\ldots$ \\
\hline Banks & 455.0 & 605.2 & 733.6 & 759.6 & $\ldots$ & $\ldots$ \\
\hline Non-bank Fis & 42.0 & 47.7 & 48.1 & 51.3 & $\ldots$ & $\ldots$ \\
\hline Public sector & 0.0 & 0.0 & 0.0 & 0.0 & $\ldots$ & $\ldots$ \\
\hline Other & 5.2 & 97.0 & 7.2 & 5.2 & $\cdots$ & $\cdots$ \\
\hline Total liabilities & 877.0 & $1,132.4$ & $1,197.1$ & $1,322.7$ & $\ldots$ & $\ldots$ \\
\hline Foreign liabilities & 280.9 & 433.7 & 481.3 & 625.0 & $\ldots$ & $\ldots$ \\
\hline Short-term debt & 30.4 & 147.9 & 163.7 & 163.9 & $\ldots$ & $\ldots$ \\
\hline IMF stand-by facility & 0.0 & 0.0 & 0.0 & 118.1 & $\ldots$ & $\ldots$ \\
\hline IMF SDR allocation & 2.6 & 2.8 & 2.9 & 3.5 & $\ldots$ & $\ldots$ \\
\hline Banks FX deposits & 0.0 & 30.6 & 67.2 & 110.9 & $\ldots$ & $\ldots$ \\
\hline Treasury FX deposits & 247.9 & 252.3 & 247.5 & 228.6 & $\ldots$ & ... \\
\hline Domestic liabilities & 596.1 & 698.7 & 715.8 & 697.7 & $\ldots$ & $\ldots$ \\
\hline Notes and coins in circulation & 12.6 & 32.1 & 28.9 & 26.4 & $\ldots$ & $\ldots$ \\
\hline Banks & 230.6 & 267.2 & 275.1 & 270.8 & $\ldots$ & $\ldots$ \\
\hline Non-bank Fis & 13.9 & 9.1 & 6.8 & 39.0 & $\ldots$ & $\ldots$ \\
\hline Public sector & 197.0 & 200.2 & 199.3 & 180.5 & $\ldots$ & $\ldots$ \\
\hline Other & 2.7 & 50.9 & 63.4 & 33.6 & $\ldots$ & $\ldots$ \\
\hline Capital and reserves & 139.3 & 139.2 & 142.4 & 147.4 & $\ldots$ & $\ldots$ \\
\hline
\end{tabular}

Sources: Central Bank of Iceland; and Fund staff estimates

1/ Takes new base, but assumes same adjustment path as projected in Table 4 of the Request for an Stand-by Arrangement Staff Report.

2/ Takes change in stock from October 21, 2008 to end-December 2008 as determined in Table 1 of LOI.

3 / Excludes deposits at the current account balances at the central bank and holdings of central bank CDs.

4/ Collateralized loan to Kaupthing ( $596 \mathrm{mn}$ euro) shown in other liabilities in Oct-08 statements was reclassified in credit to banks in Nov- 08 .

$5 /$ Includes overdue collateralized loans and excludes banks' foreign exchange deposits. 
Table 3. Iceland: Opening Balance Sheets of the New Banks (In billions of krona)

\begin{tabular}{|c|}
\hline New Landsbanki \\
\hline Revised SR 1/ \\
\hline
\end{tabular}

\section{Asset}

Cash and cash balance with Fls

Loans to credit institutions

$\begin{array}{rrrrrr}238 & 238 & 146 & 146 & 77 & 77 \\ 87 & 64 & 19 & 19 & 27 & 27 \\ 739 & 825 & 631 & 632 & 455 & 455 \\ 151 & 216 & 51 & 11 & 65 & 65 \\ 85 & 63 & 39 & 63 & 76 & 76 \\ \mathbf{1 , 3 0 0} & \mathbf{1 , 4 0 6} & \mathbf{8 8 6} & \mathbf{8 7 0} & \mathbf{7 0 0} & \mathbf{7 0 0}\end{array}$

\section{Liabilities}

Deposits from Fls and central bank

Deposits

$\begin{array}{rrrrrr}63 & 107 & 15 & 17 & 78 & 78 \\ 478 & 463 & 338 & 338 & 339 & 339 \\ 1 & 49 & 1 & 0 & 36 & 36 \\ \mathbf{5 4 2} & \mathbf{6 1 9} & \mathbf{3 5 4} & \mathbf{3 5 5} & \mathbf{4 5 3} & \mathbf{4 5 3} \\ 558 & 586 & 422 & 405 & 172 & 172 \\ 200 & 201 & 110 & 110 & 75 & 75 \\ \mathbf{1 , 3 0 0} & \mathbf{1 , 4 0 6} & \mathbf{8 8 6} & \mathbf{8 7 0} & \mathbf{7 0 0} & \mathbf{7 0 0}\end{array}$

Other liabilities

Total liabilities

Bond issue to new bank Equity

Total liabilities and equity

Source: Iceland's Financial Supervision Authority.

1/ Data presented in Request for Stand-by Arrangement Staff Report. 
Table 4. Iceland: Balance of Payments, 2007-09

(\$US billion)

\begin{tabular}{|c|c|c|c|c|c|c|}
\hline & 2007 & & 2008 & & 200 & \\
\hline & & Q1-Q3 & Program & Proj. & Program & Proj. \\
\hline Current Account & -2.9 & -3.9 & -1.8 & -5.1 & 0.1 & 0.3 \\
\hline Balance on Goods & -1.4 & -0.6 & 0.2 & -0.4 & 0.9 & 0.8 \\
\hline Merchandise exports f.o.b. & 4.8 & 4.2 & 5.8 & 5.3 & 4.9 & 4.8 \\
\hline Merchandise imports f.o.b. & -6.2 & -4.8 & -5.6 & -5.7 & -4.1 & -4.1 \\
\hline Balance on Services & -0.7 & -0.3 & -0.1 & 0.0 & 0.5 & 0.7 \\
\hline Exports of services, total & 2.2 & 1.8 & 2.7 & 2.6 & 2.6 & 2.5 \\
\hline Imports of services, total & -2.9 & -2.1 & -2.8 & -2.6 & -2.0 & -1.8 \\
\hline Balance on Income 1/ & -0.8 & -3.0 & -1.8 & -4.6 & -1.2 & -1.1 \\
\hline Receipts & 5.0 & 1.4 & 3.9 & 1.2 & 0.3 & 0.0 \\
\hline Expenditures & -5.9 & -4.4 & -5.6 & -5.8 & -1.5 & -1.1 \\
\hline Current transfer, net & -0.1 & 0.0 & 0.0 & -0.1 & 0.0 & 0.0 \\
\hline Capital and Financial Account & 2.8 & 7.5 & -17.1 & -10.2 & -2.1 & -2.2 \\
\hline Capital transfer, net & 0.0 & 0.0 & 0.0 & 0.0 & 0.0 & 0.0 \\
\hline Financial Account & 2.8 & 7.6 & -17.1 & -10.2 & -2.1 & -2.2 \\
\hline Direct investment, net & -9.1 & 1.9 & -0.7 & 3.3 & 0.3 & 0.2 \\
\hline Abroad & -12.2 & 2.2 & 0.5 & 3.6 & 0.0 & 0.0 \\
\hline In Iceland & 3.1 & -0.3 & -1.3 & -0.3 & 0.3 & 0.2 \\
\hline Portfolio investment, net & -6.8 & 2.0 & 1.9 & 1.5 & -1.3 & -1.5 \\
\hline Assets & -7.6 & 1.5 & 0.1 & 1.5 & -1.3 & -0.9 \\
\hline Liabilities 2/ & 0.8 & 0.6 & 1.9 & 0.0 & 0.0 & -0.6 \\
\hline o/w new borrowing debt securities & $\ldots$ & $\ldots$ & 2.5 & 1.8 & 1.5 & 1.3 \\
\hline amortization debt securities & $\ldots$ & $\ldots$ & -0.9 & -1.2 & -1.5 & -1.5 \\
\hline other & $\cdots$ & $\cdots$ & 0.3 & -0.6 & 0.0 & -0.4 \\
\hline Other investment, net $2 / 3 /$ & 18.7 & 3.7 & -18.3 & -15.0 & -1.0 & -0.9 \\
\hline Assets & -16.8 & -2.4 & -3.0 & -2.4 & 1.1 & 0.0 \\
\hline o/w asset recovery & $\ldots$ & 0.0 & $\ldots$ & 0.0 & 2.1 & 0.5 \\
\hline other & $\ldots$ & 0.0 & $\ldots$ & 0.0 & -1.0 & -0.5 \\
\hline Liabilities 2/ & 35.5 & 6.1 & -15.4 & -12.6 & -2.1 & -0.9 \\
\hline o/w new borrowing 4/ & $\cdots$ & $\ldots$ & 1.9 & 5.8 & 0.0 & 0.5 \\
\hline amortization 4/ & $\cdots$ & $\cdots$ & -1.5 & -2.6 & 0.0 & -0.9 \\
\hline short-term debt & $\ldots$ & $\ldots$ & 0.2 & 0.2 & 0.2 & 0.2 \\
\hline short-term debt amortization & $\cdots$ & $\cdots$ & -0.2 & -0.2 & -0.2 & -0.2 \\
\hline banks foreign deposits & $\ldots$ & $\ldots$ & -15.8 & -15.8 & $\ldots$ & $\ldots$ \\
\hline amortization of deposit insurance loans & & & & & -2.1 & -0.5 \\
\hline Net errors and omissions & 0.4 & -2.5 & 0.4 & -2.1 & 0.0 & 0.0 \\
\hline Overall Balance & 0.2 & 1.2 & -18.5 & -17.5 & -2.0 & -1.9 \\
\hline Financing & -0.1 & -1.2 & 18.5 & 17.5 & 2.0 & 1.9 \\
\hline Reduction in reserves & -0.1 & -1.2 & -3.0 & -0.9 & 0.6 & -1.9 \\
\hline Accumulation of arrears 2/ & $\ldots$ & $\ldots$ & 10.3 & 17.6 & 0.0 & -5.8 \\
\hline Extraordinary Financing 5/ & $\ldots$ & $\ldots$ & 11.2 & 0.8 & 1.4 & 9.6 \\
\hline IMF & $\ldots$ & $\ldots$ & 0.8 & 0.8 & 0.6 & 0.6 \\
\hline Bilateral (earmarked/ non-cash) & $\cdots$ & $\cdots$ & 8.2 & $\cdots$ & 0.0 & 5.8 \\
\hline Other identified new financing & $\cdots$ & $\cdots$ & 2.2 & $\cdots$ & 0.8 & 3.2 \\
\hline Level of Gross reserves (eop) & 2.6 & 3.7 & 5.6 & 3.5 & 5.0 & 5.4 \\
\hline
\end{tabular}

Sources: CBI; and IMF staff estimates.

$1 /$ Includes interest payments due from the financial sector and income receipts to the financial sector in 2008.

2/ 2008 Q1-Q3 flows are net and include banking sector flows; 2008 includes estimates for gross flows only for Q4.

$3 /$ Includes possible arrears accumulated by the financial sector in 2008 . From 2009 onwards, and so as not to prejudge the outcome of the banking sector resolution, arrears are not recorded in the BOP and are assumed to have been paid off through asset recovery or written down in the bankruptcy process.

4/ In 2008 includes short term debt of the banking sector.

$5 /$ Debt service on extraordinary financing is shown in the capital account, except for repurchases from the Fund. 
Table 5. Iceland: Quantitative Performance Criteria Under the 2008 Economic Program

\begin{tabular}{c}
$\begin{array}{c}\text { Performance } \\
\text { Criteria }\end{array}$ \\
\hline December 2008 \\
Ceiling/Floor 1/
\end{tabular}

\section{Indicative Targets}

\begin{tabular}{cc}
\hline March 2009 & June 2009 \\
Ceiling/Floor 2/ & Ceiling/Floor 3/ \\
\hline
\end{tabular}

(In billions of Króna)

$-12$

25

25

25

$-55$

50

50

Bank of Iceland to the private sector $5 /$
3. Ceiling on the change in the domestic claims of the Central Bank of Iceland to the central government

1. Floor on the change in the central government net financial balance 4/

2. Ceiling on the change in net credit of the Central government 
Table 6. Iceland: Structural Conditionality

\author{
Structural Conditionality
}

Status

\title{
Prior Actions
}

- Raise the policy interest rate to 18 percent.

- Establish a committee comprising representatives from the Prime Minister's Office, the Financial Supervisory Authority, the Central Bank of Iceland, the Ministry of Finance, and the Ministry of Commerce to coordinate policy input and will be chaired by the expert in charge of the bank restructuring process.

\section{Structural Performance Criteria}

- A capital injection into the three new banks, made using tradable government bonds issued on market terms, to raise the capital adequacy ratio to at least 10 percent. By end-February 2009.

- An experienced banking supervisor to provide an assessment (to be published) of the regulatory framework and supervisory practice, including the framework of rules on liquidity management, connected lending, large exposures, cross-ownership, and the "fit and proper" status of owners and managers, and propose needed changes. By end-March 2009.

\section{Structural Benchmarks}

- Develop a strategy for asset recoveries. By end-November 2008.

- Prepare plans to embark on medium-term fiscal consolidation. By end-2008.

- FME to review the business plans of each of the new banks. By January 15, 2009.

- International Auditing Firm to conduct valuations of the old and new banks using a methodology in accordance with international best practice. Complete by end-January 2009.

- Improve the medium-term fiscal framework. By end-June 2009.
- Done.

- Done.

- The authorities reported that delays in asset valuation will affect the timetable for bank recapitalization.

- The authorities reported that an expert has been hired to make an assessment of regulatory and supervisory practices, and should complete the assessment by endMarch.

- Done.

- The authorities have started to cost the implications of some of the 2009 measures for the medium term.

- Two of the three new banks have already submitted business plans for review. The authorities expect all three to have plans in place by mid-January.

- The authorities reported that the process is behind schedule. There has been difficulty reaching agreement with both creditors and auditors on a common methodology according to which the banks will be valued. The authorities believe that the work can be complete by end-February or early March.

- The authorities expect by late-January to have identified the broad areas of focus for medium-term fiscal consolidation. 
Transaction

Residents
Transfers are free, payments are free, however transactions must be verified.

Imports of goods and services,
invisibles including income

Repatriation requirements

Controls on direct investment and derivatives

Loans

Gifts, endowments and other transfers

\section{Exports and imports of} banknotes

Foreign exchange accounts

Accounts in domestic currency
Shares, financial instruments
Foreign exchange receipts must be repatriated to Iceland and sold or deposited to a foreign currency account with an $A D$.

Free.

New investment in securities and other financial instruments is not permitted in foreign currency. Derivatives between residents and nonresidents are not allowed except for trade in goods and services.

Commercial credits are free. Lending to nonresidents is allowed only for loans with a maturity of at least one year and in an amount not exceeding ISK10,000,000 a person a calendar year.

Not allowed except for amounts not exceeding ISK10,000,000 a calendar year.

Export of foreign currency is not permitted

Transfer abroad for capital transactions is not allowed with the exception of FDI and real estate transactions.

Domestic currency accounts are not convertible for capital transactions. above ISK50.000 a person a month.

\section{Nonresidents}

Proceeds from the sale of goods and services to Iceland are freely transferable. Proceeds including dividends, profits, interest are freely transferable.

N.A.

Free, except for transfer abroad of proceeds from sale of FDI. (Serves antiavoidance purposes)

Nonresidents may invest in securities and financial instruments only in krona, however, proceeds from the sale of such securities are not convertible and transferable.

Commercial credits are free. Borrowing from nonresidents is allowed only for loans with a maturity of at least one year and in an amount not exceeding ISK10,000,000 a person a calendar year.

Not allowed except for amounts not exceeding ISK10,000,000 a calendar year.

Export of foreign currency is not permitted above ISK50.000 a person a month.

Transfers abroad are free.

Proceeds from capital transactions (except for FDI) must be credited to króna accounts. Balances may be used only in Iceland.
Comments
Strengthen structured cooperation with FME to ensure the monitoring of banks' compliance with controls. Compliance of banks is necessary to the effective implementation of the controls.

Closely monitor repatriation of export proceeds at an aggregated level by using customs and transfer data.

Explore other, less intrusive, ways of preventing circumvention of controls.

Frequently review control to relax excessively stringent rules and to close loopholes. Establish limits for short-term overdrafts for banks to avoid that rules stifle normal banking operations on the long run.

Revise reporting requirements to ensure that the $C B$ I receives all information it needs for managing the foreign exchange regime in a timely manner.

Establish a forum to discuss control-related issues with commercial banks and investors regularly. This would help to detect loopholes and address concerns of investors by issuing guidelines or lifting controls. 
Table 8. Iceland: Summary Operations of the General Government, 2005-09 (in percent of GDP)

\begin{tabular}{|c|c|c|c|c|c|c|c|}
\hline & \multirow[t]{2}{*}{2005} & \multirow[t]{2}{*}{2006} & \multirow{2}{*}{$\frac{2007}{\text { Prel. }}$} & \multicolumn{2}{|c|}{2008} & \multicolumn{2}{|c|}{2009} \\
\hline & & & & CR 08/362 & Proj. 1/ & CR 08/362 & Proj. 1/ \\
\hline Total revenue & 48.8 & 49.7 & 50.0 & 45.3 & 45.3 & 41.7 & 40.5 \\
\hline $\begin{array}{l}\text { Current revenue } \\
\text { of which: }\end{array}$ & 47.0 & 48.0 & 48.2 & 43.8 & 43.8 & 40.0 & 38.8 \\
\hline $\begin{array}{l}\text { Direct taxes } \\
\text { of which: }\end{array}$ & 21.0 & 21.6 & 21.8 & 19.2 & 20.0 & 17.5 & 17.6 \\
\hline Corporate income tax & 2.1 & 2.4 & 2.7 & 1.7 & 2.2 & 1.3 & 1.4 \\
\hline Personal income tax & 14.3 & 13.9 & 13.9 & 12.6 & 12.5 & 12.4 & 12.3 \\
\hline Social security contributions & 3.2 & 3.3 & 3.1 & 2.8 & 2.7 & 2.8 & 2.6 \\
\hline Capital tax and rental income & 1.4 & 1.9 & 2.2 & 2.1 & 2.6 & 1.1 & 1.3 \\
\hline Indirect taxes & 19.5 & 19.8 & 19.2 & 17.0 & 16.2 & 15.2 & 14.9 \\
\hline Interest income & 1.0 & 1.7 & 2.3 & 2.5 & 2.8 & 2.2 & 1.3 \\
\hline Other current income & 5.5 & 4.8 & 4.9 & 5.1 & 4.8 & 5.1 & 5.1 \\
\hline Capital revenue & 1.8 & 1.8 & 1.8 & 1.5 & 1.5 & 1.7 & 1.7 \\
\hline Total expenditure & 44.0 & 43.4 & 44.5 & 45.5 & 45.5 & 55.2 & 54.3 \\
\hline $\begin{array}{l}\text { Current expenditure } \\
\text { of which: }\end{array}$ & 40.1 & 38.9 & 39.7 & 39.7 & 39.7 & 48.7 & 48.7 \\
\hline $\begin{array}{l}\text { Operational cost } \\
\text { of which: }\end{array}$ & 28.1 & 27.7 & 27.7 & 27.2 & 27.2 & 29.9 & 30.4 \\
\hline Wages and salaries & 15.6 & 15.3 & 15.3 & 16.2 & 16.2 & 17.3 & 17.3 \\
\hline Purchase of goods and services & 7.2 & 7.3 & 7.2 & 9.5 & 9.5 & 10.8 & 11.3 \\
\hline Interest expenditure & 2.2 & 2.2 & 2.6 & 2.1 & 2.1 & 7.3 & 6.3 \\
\hline Subsidies & 2.0 & 1.7 & 1.8 & 1.6 & 1.6 & 1.6 & 1.6 \\
\hline Income transfers & 6.7 & 6.3 & 6.4 & 7.3 & 7.3 & 8.4 & 8.9 \\
\hline Other expense & 1.1 & 1.0 & 1.2 & 1.4 & 1.4 & 1.6 & 1.6 \\
\hline Capital expenditure & 3.8 & 4.6 & 4.8 & 5.8 & 5.8 & 6.5 & 5.6 \\
\hline Financing gap/measures & 0.0 & 0.0 & 0.0 & 0.0 & 0.0 & 0.0 & 0.0 \\
\hline Primary balance & 6.1 & 6.7 & 5.8 & -0.6 & -0.9 & -8.5 & -8.8 \\
\hline Overall balance & 4.9 & 6.3 & 5.5 & -0.2 & -0.2 & -13.5 & -13.9 \\
\hline Commercial bank restructuring & 0.0 & 0.0 & 0.0 & 25.8 & 0.0 & 0.0 & 0.0 \\
\hline Central bank recapitalization & 0.0 & 0.0 & 0.0 & 0.0 & 0.0 & 10.0 & 18.7 \\
\hline Depositor insurance & 0.0 & 0.0 & 0.0 & 47.0 & 0.0 & 0.0 & 24.4 \\
\hline Other 2/ & 0.0 & 0.0 & 0.0 & 0.0 & 2.7 & 0.0 & 0.0 \\
\hline Augmented balance & 4.9 & 6.3 & 5.5 & -73.0 & -2.9 & -23.5 & -57.0 \\
\hline Financing & -4.9 & -6.3 & -5.5 & 73.0 & 2.9 & 23.5 & 57.0 \\
\hline Net foreign financing (budget) & .. & .. & .. & 0.0 & 0.0 & 0.0 & 0.0 \\
\hline Special foreign loans (depositor) & .. & .. & .. & 47.0 & 0.0 & 0.0 & 32.5 \\
\hline Net domestic financing (budget) & .. & .. & .. & 0.2 & 0.2 & 13.5 & 13.9 \\
\hline Asset recovery/reduction of foreign loans & .. & .. & .. & 0.0 & 0.0 & -14.0 & -8.1 \\
\hline Special domestic loans (bank restr.) & .. & .. & .. & 25.8 & 2.7 & 10.0 & 18.7 \\
\hline \multicolumn{8}{|l|}{ Debt position } \\
\hline General government gross debt & 25.4 & 30.1 & 28.9 & 108.9 & 40.2 & 108.6 & 83.3 \\
\hline General government net debt & 9.4 & 7.8 & 7.3 & 90.6 & 17.5 & 97.0 & 71.7 \\
\hline \multicolumn{8}{|l|}{ Cyclically adjusted } \\
\hline Primary revenue & 46.8 & 46.5 & 45.7 & 41.6 & 41.2 & 41.4 & 41.2 \\
\hline Primary expenditure & 42.7 & 42.6 & 43.9 & 45.4 & 45.4 & 45.4 & 45.5 \\
\hline Primary balance & 4.1 & 3.9 & 1.8 & -3.8 & -4.1 & -3.9 & -4.2 \\
\hline Total revenue & 47.8 & 48.3 & 48.1 & 44.2 & 44.2 & 43.6 & 42.4 \\
\hline Total expenditure & 45.0 & 44.8 & 46.6 & 47.6 & 47.6 & 52.2 & 51.4 \\
\hline Overall balance & 2.9 & 3.5 & 1.5 & -3.4 & -3.4 & -8.7 & -9.0 \\
\hline \multicolumn{8}{|l|}{ Memorandum items: } \\
\hline Real expenditure change & 1.8 & 5.3 & 8.1 & 4.5 & 4.5 & 6.6 & 4.9 \\
\hline Output gap & 2.3 & 3.2 & 4.8 & 4.6 & 4.6 & -5.4 & -5.4 \\
\hline Change in structural primary balance & 1.8 & -0.2 & -2.1 & -5.6 & -5.9 & -0.1 & -0.1 \\
\hline
\end{tabular}

Sources: Ministry of Finance; and Fund staff estimates and calculations.

1/ Projections reflect updated preliminary information on central government finances only.

2/ Losses due to bad quality collateral held from securities lending with failed banks.

3/ For 2009 projection, this includes a loan to recapitalize the central bank, as well as a non-loan operation to recapitalize commercial banks. 
Table 9. Iceland: Budget Measures (ISK billion)

\begin{tabular}{|c|c|c|c|c|}
\hline & 2009 & 2010 & 2011 & 2012 \\
\hline Necessary measures $1 /$ & 45.0 & 47.0 & 27.0 & 37.0 \\
\hline Identified measures & 42.0 & .. & .. & .. \\
\hline \multicolumn{5}{|l|}{ Of which: } \\
\hline Revenue measures & 7.0 & .. & & .. \\
\hline - Increase PIT by 1 percent $2 /$ & 7.0 & \multicolumn{3}{|c|}{--- permanent --- } \\
\hline Expenditure measures & 35.0 & .. & & .. \\
\hline Reduce transfer payments $3 /$ & 11.0 & .. & & .. \\
\hline - Reform indexation of benefits to elderly and people without an income & 4.0 & \multicolumn{3}{|c|}{--- permanent --- } \\
\hline - Limit indexation of benefits to farmers to 5.7 percent & 0.8 & \multicolumn{3}{|c|}{.. $\quad .}$. \\
\hline - Reduce transfers to the student lending fund & 1.0 & \multirow{2}{*}{\multicolumn{3}{|c|}{$\begin{array}{l}. . \\
---\end{array}$}} \\
\hline $\begin{array}{l}\text { - Limit maternity leave benefits, alter meanstesting for elderly } \\
\text { (exempt income floor is lowered, interest income increasingly means-tested) }\end{array}$ & 0.8 & & & \\
\hline - Eliminate government contribution to the rehabilitation fund for the disabled & 0.5 & \multirow{2}{*}{\multicolumn{3}{|c|}{--- permanent --- }} \\
\hline - Cut development assistance & 1.2 & & & .. \\
\hline - Increase co-pay on contracts with private healthcare practioners & 1.0 & \multicolumn{3}{|c|}{--- permanent --- } \\
\hline - Reduce payments to religious communities & 0.3 & \multicolumn{3}{|c|}{--- permanent --- } \\
\hline - Other misc. items & 1.4 & .. & .. & .. \\
\hline $\begin{array}{l}\text { Reduce operational expenditures } 4 / \\
\text { - Reduce non-wage operational spending by } 3-5 \text { percent } 5 / \\
\text { - Postpone new expenditure projects }\end{array}$ & 13.0 & \multicolumn{2}{|l|}{.. } & .. \\
\hline Cut investment spending & 11.0 & .. & .. & .. \\
\hline $\begin{array}{l}\text { Other measures under consideration } \\
\text { Of which. }\end{array}$ & 3.0 & .. & .. & .. \\
\hline $\begin{array}{l}\text { Further misc. cuts in transfer payments } \\
\text { Funt }\end{array}$ & .. & .. & .. & .. \\
\hline Further misc. cuts in capital expenditures & .. & .. & .. & .. \\
\hline
\end{tabular}

1/ Measures for 2009 are relative to the pre-crisis budget, i.e. before adjustments to inflation.

2/ In addition local governments (LGs) will be allowed to raise PIT taxes by 0.25 percent.

3/ Transfer to LGs will be lowered, but this will be offset by an increase in the equalization fund, and potentially higher PIT. In addition, property tax levied by LGs will, contrary to earlier plans, not be lowered.

4/ Public wages are budgeted to increase by 3 percent from March 1, 2009 onward, and a contingency margin for a further 2.1 percent increase is included.

5/ Government agencies: 5 percent; Police, welfare (incl. health and education): 3 percent. 